\title{
Interview
}

\section{In conversation with Brian Abel-Smith}

Hugh Freeman interviewed Professor Abel-Smith in London recently.

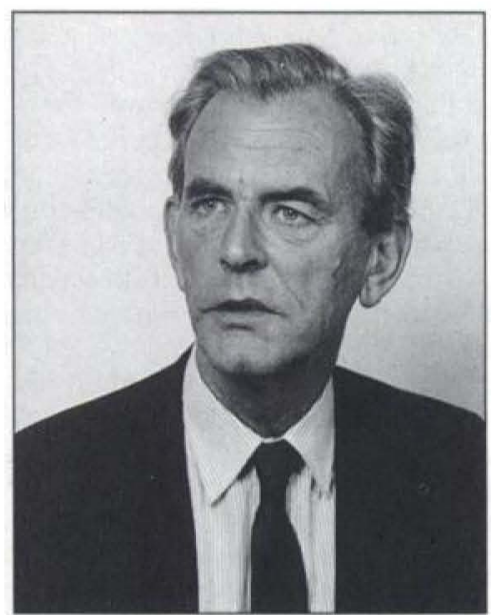

Brian Abel-Smith, Professor of Social Administration, University of London at the London School of Economics since 1965.

Mental health services in this country have developed over the last 40 years, I think, as an expression of the Welfare State and particularly of the National Health Service. Is there any aspect of this situation you would regard as particularly important?

Well obviously, there is the trend to community care, which we're increasingly worried about - as to whether it really is care

Community care has been talked about since the 1950s, but it's been suggested that, at least until now, there was never in fact the scale of money available in the public sector that could have created a structure of that kind. In other words, that it was more talk than action. Do you think that's a reasonable comment?

I think it is; the start-up money wasn't available at the right time. But the interesting thing is the enormous investment which has been put into hospitals, since the NHS began, which alternatively might have been put into community services. Standards per head in the hospitals have been enormously improved, and my goodness they needed it, but looking back, it seems that things might have been better managed in that respect. The real difficulty into which we've got now is the enormous restraint on social services expenditure which is the Government's policy. I believe this will make the implementation of Griffiths difficult, if not impossible, unless there is some relaxation in that respect.

When you talk about the improvement in hospital services, which of course has been enormous since 1948, that's largely an improvement in terms of revenue, isn't it? One of the striking things about the earlier period is that the NHS was remarkably unsuccessful in getting capital for building, as opposed to improving the staffing. Why do you think this was the case for so many years, compared say, with education or housing?

I can see that politically, when you simply have no schools for an increasing number of children, that is obviously going to take priority over replacing bad hospital buildings. And of course, the only new hospital built in the 1950s was a mental handicap one, apart from some readjustment to make room for the fall in tuberculosis beds. But the interesting thing is to contrast this situation with other countries, where very often, when hospitals were independent, they had the right to borrow their own money and to run depreciation into their charges, so that they were more free-standing. One of the prices we pay for having a National Health Service is that its cost is all part of the public expenditure total and therefore, decisions do get made between competing priority areas. Also, public housing came out of the same pot in terms of capital and, particularly in the Macmillan years, that was the dominating priority right through to the end of the sixties. Many people then were so poorly housed, though, that I can understand that being a political priority. So health lost out, and then we started building too late to be able to make the sort of progress which had occurred in some other countries. Even within the mental health sector, mental health inevitably did not figure largely - in fact, fell pretty well near the bottom of the queue. This was for the very good reason that technological developments in the acute services were very great, and needed a lot more space in different types of buildings, while it was difficult to see these developments affecting the mental health area, at least in terms of their space requirements. Of course, a lot of the mental health buildings were inadequate, and one would have built them in a different way, if one was to start again today. 
In his history of the NHS, Charles Webster recounts how when some money was eventually allocated specifically for mental handicap or mental illness building, it was hardly ever spent in fact, because the administrative structure was incapable of spending it - there were such delays and difficulties in actually approving projects and getting them built. Do you think that this administrative blockage was in fact a significant element in the slow improvement of the NHS capital stock?

I think you are referring to Macleod's 'mental million'. In Britain, we had no idea how slow and complicated building hospitals was in the post-war period, until we attempted to do it on a big scale, with the Powell Plan. That soon showed up the problems of the administrative procedures, but also, the architects at that stage were not used to this type of very complicated building, which was needed for the acute sector at least. That's one of the lessons we eventually learned. But part of the problem was the process of approval; the debates between the DHSS architects and those being used locally - about keeping the cost down and about what was appropriate resulted in an awful lot of tetchiness at that level, which could delay a scheme for a year or two.

As an historian of the health services, have you not been struck by the remarkable speed by which very many large buildings were put up in the earlier periods, without any technological help. Was there something about administrative processes earlier, perhaps, which we lost in more recent times, and which prevented us from getting things actually constructed?

Well, it was remarkable that the Poor Law Infirmaries and the psychiatric hospitals were sometimes built in as little as six or nine months, but this would have been a vast, thousand-bedded institution, and they were basically pretty simple. They were made in traditional materials, and it's quite remarkable how well they've lasted, but of course, later on, one had to insert all the electricity and plumbing and so on, up to modern standards. I think the essence of hospital construction now is trying to incorporate all these complicated things from the start.

In the last century, on the whole, the State took little interest in the lives of its citizens, apart from keeping the peace. Yet in the case of insanity and the mental hospitals, there was very large public investment, and they were quite complicated services in the sense of the time. Why do you think insanity and asylums had this very special place in the public sector in the mid-19th century?

They were certainly given priority from central Government funding on a scale which the rest of the Poor Law infirmaries did not get. I've always assumed this was partly through concern about law and order, and later with the concern about eugenics - rather like the same attitude to prisons.

Do you think humanitarianism also had a part in that the tradition which stemmed from voluntary infirmaries of the 18th century and of Moral Treatment from The Retreat?

Well it might have been, but then one has to ask the question - why was more priority not given to building general hospitals? Part of the reason was a belief that you musn't compete with the voluntary hospital movement - which was doing a marvellous job, and that was the way it should be done - but there never was much of a voluntary hospital movement for the mentally ill, though there was, of course, a quite substantial private sector.

Right up to 1930, the asylums were intimately involved with the Poor Law-in some ways were an actual expression of that Law. Have you a view as to why this association was so close?

I don't think I can really answer that question, though they were both under local government, and therefore to some extent were seen along similar lines. Of course, part of what was going on in the late 19 th and early 20 th centuries was a continuous process of sorting people out and transferring them to specialised institutions, and that process included the mentally ill and mentally handicapped. From the point of view of the Poor Law authorities, that was marvellous, because then these people were off their books, and went on to a different type of funding until, under the 1929 Act, everything came more or less out of the same pot.

You have been the historian of Britishnursing and in this country, we have had a special tradition of mental nurses which is different from almost all other countries. How do you think that tradition has influenced the development of mental health services in general?

That's a very interesting question. When I did write about nurses, I soon realised that mental nurses were quite a different cup of tea from the mainstream and I left them out of the study. But of course, the custodial, prison-like tradition, countil g patients, and so on, requires tough men and women. So they were aiming to recruit different types of people for different purposes, and therefore developed separately from the Miss Nightingale tradition. I don't think Florence Nightingale took much interest in mental hospitals. If she had, she might have seen mental and general nursing as a common type of activity, and tried to spread her type of influence by getting well-educated people into the psychiatric nursing service, but she didn't.

In the post-war period, did you have any particular views about the special mental nursing tradition in Britain, contrasting it with other industrialised countries?

Well, I was worried in the 50 s and 60 s about standards of care and the old custodial tradition. That was what I heard and knew from students who worked in psychiatric hospitals for short periods what it was really like when the doctors weren't there. That's why I didn't regard as incredible what Mrs 
Robb had discovered and said in Sans Everything about the bad conditions of many elderly patients. She was absolutely right to form an organisation to try and do something about it. For one woman who had really very little background in the mental hospital area - she was a psychotherapist - to suddenly do so much in such a short period - and tragically, to die so soon - is a remarkable story. It has now been written up by one of my students.

I think the scandals of the 60s and early 70 s were on the whole rather more about psychogeriatrics and mental handicap than they were about mental illness, and one could perhaps argue that these were not the core activities of the mental health services. It was really from the 1950s that the mental hospital took on a significant psychogeriatric function. Do you think that this process in some way distorted the way that mental health services developed here? In other words, if the care of the elderly had included the elderly mentally ill and had been clearly in a separate category, as it is in many countries, would things have been very different?

I don't know. I hadn't really thought about that question. I have always attributed the fact that the scandals were concentrated outside mainstream psychiatry to the likelihood that it's more difficult to get credible evidence about what's going on in a psychiatric hospital. And that is probably inevitable with the very strong sanctions which can be put against a member of the nursing or other staff who rocks the boat, particularly in an isolated institution. I had the feeling of very strong internal control among both nursing and ancillary staff and a very strong tradition about supporting each other and keeping quiet about perks, and so on. That was all part of the mental hospital tradition.

The living standards of nurses, let alone patients, were abysmally low in the 50s and 60s, and at a time of full employment, it was very difficult to recruit staff in those circumstances. Do you think that this in some ways caused a deterioration of morale? Did you see the scandals as a form of deliberate brutality, or rather as resulting from neglect by a rather demoralised work force?

A bit of both. I think it was partly due to the oldfashioned custodial attitudes and discipline, which stemmed from the 19th century, combined with very tough attitudes to patients. There were all sorts of punishments for patients who broke the rules, which were legitimised in practice, though later they were theoretically no longer available. That was one stream of causes, but the other one was having poorly paid staff, the older ones having been recruited in the 1930s - the years of unemployment. People from depressed areas knew there was a secure job available in mental hospitals - if not one they would have actually chosen; they hadn't mostly gone into it out of a sense of vocation. Then there was the isolated community of the mental hospital - for the nurses, like the patients.
I know we have to avoid matters on which you were involved as a temporary civil servant and therefore covered by the Official Secrets Act, but I think that Sans Everything and the subsequent scandals were really quite effective in influencing policy within the Ministry and in the creation of the Hospital Advisory Service. Any comments you would like to make on that?

I think these events were very influential, though I've always been slightly puzzled about it and never really satisfied myself as to why it was that Richard Crossman made this such a personal crusade, for the only two years that he was in the Cabinet. But with him, it was definitely as much a personal crusade to try and get things right as it was for Barbara Robb to draw attention to what was wrong. Most people don't realise the extent to which the change was initiated by Crossman, but he started a movement which, once the Department had got on to it, took on its own momentum. This was what a great minister can do. Long after he had died, the ripple effects of the whole thing were still going on. I don't usually go for the 'great man' thesis in history, but he will be remembered, or ought to be remembered, as a rather unlikely person to have done something like this.

Were there any other particular Crossman initiatives or changes in that relatively short period?

That was his major activity, but of course he was also concerned to get a proper reorganisation of the National Health Service. He foresaw the enormous importance of co-terminosity between NHS and local government boundaries and, as his diaries make clear, was disappointed with the majority report of the Royal Commission on Local Government. He thought the minority report, which went for smaller authorities, was the better one. He was annoyed when Crosland just shouted the Report through, without any real discussion or dissension in the Government, and I think it saddened him that this was a wasted opportunity. Crossman had a hidden feeling that within 10 or 20 years, the Health Service would be the responsibility of local government.

Hasn't that been the persisting theme all along? Going back to Charles Webster's history, he suggests that one of the main reasons that Bevan nationalised all the hospitals was his realisation that to put specialist services under local authorities would be an extremely unpopular move, which he would have great difficulty getting through the medical profession. This story has, of course, been through many cycles but, would you, from this point, see the Health Service eventually as a local government function?

I have never really felt that this was an ideal option at least with the existing form of local government. I would have thought that the unwillingness of politicians to contemplate a transfer to local government has been greater in the last 20 years, because of the enormous varieties of types of local government 
which have come into being, and because of the different character of representation in local government, compared with what we had in earlier periods. I don't think this will come about, but one option is that of a specially elected local health authority. That would be very difficult to undertake and would create many problems. The crucial questions which have to be answered before you can even contemplate such an arrangement are -is it going to get this money from local income tax, and would any government be willing to delegate the right to local health authorities, whatever they were called, to fix the rate of such a tax? I just don't believe that it would. Under any government, this would need an enormous decentralisation of power, which the trend of thinking of the present government is certainly against. But I'm totally aware that Labour governments as well as Conservative want to concentrate power in their own hands and get done what they themselves want done. So I can't see this happening. Unfortunately, local government, as it exists, hasn't improved its reputation with either of the two major political parties in the last 50 years.

Would you feel that the strategy from 1948 of having special authorities, with their money coming from the Treasury, was basically the correct one?

I think it was. But what comes increasingly into my mind now is to ask whether Seebohm was really right and whether the personal social services, which are intimately connected with health, might have been better in the hands of the Health Authorities. As it is, they have been left with low priority, and possibly increasingly low priority in social services departments, because of the overwhelming public concern with child abuse.

On the question of social services, I think there have been two main arguments against their integration with health. One is that the whole organisation would then get too big-like the American HEW Departmentand secondly, the question where do you stop if health and social services are combined? Why not housing, or other things?

For a start, one could say that the question of the home help service is intimately connected with health, as are the old age homes. The problem is, indeed, how exactly do you draw the line? It has always presented a difficulty. But what I look at particularly now is the reform proposed for the Netherlands, which seems to me to be a much better one than 'Working for Patients'. It goes much further than Griffiths on community care, having the same agencies with a common fund for health and related social services. It seems to me that the Dutch have developed something logical here: if one wants to contract out services, why stop at some of the crucial parts of the contract, which involve the option of community care? This is one of the things which I suspect will come to the fore in the next ten years.
Could you speculate more about how you see community care trends developing in the immediate future? It may well become a function of health authorities to do community care, rather than for local authorities to arrange it. This may involve making special arrangements though local authority housing departments, though of course, their future is uncertain. But in the long run, I wouldn't be surprised - and it might be better - if the related social services became the responsibility of health authorities, so that the District would contract to them, as they could contract to the hospitals. However, a lot depends on who wins the next election as to whether this is really going to come in and what the attitude of a new government will be to a reform which is underway, as it probably will be by that time. In the short term, I see the future of community care as bleak.

You have suggested, I think, that there have been, in relation to hospital and community services, some missed opportunities in the early period.

I feel the missed opportunity was at the period of the Heath Government, which gave an awful lot of money to personal social services; that would have been the time at which an enormous thrust towards deinstitutionalisation and the proper development of alternatives to hospitals could have become a priority. But of course, so much was going on then. The social services departments were in the process of establishing themselves and there was the new responsibility for the disabled, which some authorities were taking very seriously indeed. Probably it would have been extremely difficult for these new departments to have developed in such a way that they replaced much long-term hospital care, but I think it was a period in which they could have been pushed to see how fast they could have moved. Difficulties would certainly have come by 1976 , with the IMF crisis, but that was a possible era in which more could have been done. I think it was indeed a missed opportunity.

From the very beginning of money being suggested or requested for community services, the Treasury's answer has been that they couldn't do that as long as the existing long-stay institutions were swallowing up so much. Do you think that was a reasonable answer and that the institutional sector could have been much reduced much earlier on?

I think it could be a reasonable answer, but there is always a short-term Treasury view. It needed startup money to do it, and that's what has never been readily available on a sufficient scale, because you have to put money into community care before you can discharge people to it. That is a typical Treasury problem - you can't have the money because you are already spending it one way, and we're not prepared to invest in an alternative so that you can change. This is one of the sorrows of the thing-a lack of vision and the effect of short-term thinking. 
Going back to the Hospital Plan in 1962 and to the Community Care plan of the following year, these were, I think, rather less than plans. They were rather more aspirations and ideas in many cases. If you totalled up at the time what the cost of the whole would have been, it was far more than any allocations that could possibly have been made. Do you think the Hospital Plan was basically unrealistic from that point of view, and to some extent the Community Care Plan also?

Well, they've proved to be unrealistic, but nobody could have foreseen the economic troubles of the late 60 s at the time. I think they were very bold and a great credit to Enoch Powell for having produced them and forced people to think about them. Of course, it was the period of optimism - we had never had it so good of considerable economic growth, before we got the pessimism about the British economy. Therefore, I don't criticise anyone for doing it at the time. Whether it would have been impossible to do altogether is another question. If, for example, it had been possible to find a way of putting money into housing through the private sector, rather than all that massive construction under Crossman of unsatisfactory, as we now see it, public high-rise buildings, there might have been more money available for the health sector. If the potential of the housing association, which was to be developed in the 1970s had been recognised earlier, this might have been possible. Crossman was being pushed by his advisers to do this, but it only happened then on a very small scale.

Before the 1974 reorganisation, I was present at one of your seminars, and I think it was clear fairly soon that the area-district relationship was a problem. Do you think that was really a mistake from the beginning?

I do think it was a mistake from the beginning, and the delay in doing something about it was the result of having set up the Royal Commission on the NHS. We couldn't very well set up such a Commission and then carry out recommendations that it was likely to make, before it reported. This was always the difficulty, as it was quite clear by 1976 that the recognised system was not working well. It represented the view, which I do not hold, that the long-term future is that existing local authorities should have the Health Service transferred to them. If you don't accept that, then a structure which had been connived to make that a possibility-by having health authorities co-terminous with local authorities - created one tier too many, and that was a tragedy.

The Health District, I think, was a concept which developed rather slowly and probably had not been fully thought out at the time the 1974 reorganisation was being implemented. Do you accept that view?

Well no. A debate was going on about what the proper size of the unit for running major hospital services would be, and of course, the person who clearly saw that the District was the crucial area was Sir George Godber, the Chief Medical Officer. But politicians thought they could build this local link with the personal social services. It never really came off very well, and the invention of transferrable money on a small scale showed that at the beginning, there was concern that this was not working well. It's a mistake to think that co-terminosity of boundaries necessarily creates good working relationships and collaboration. It doesn't.

Do you think the health district has now reached some sort of ultimate expression? Is this something that is likely to stay with us for quite a long time?

Oh I think it will. It's got a logic behind it and really represents an evolution from the stage in which the psychiatric hospital management committees were separated administratively from the rest in 1948. Now, they've gone through a process of amalgamation, and mental illness and mental handicap have been brought into the mainstream of local services.

Even with enthusiasm for community care, there is still a group of patients with chronic psychiatric handicaps who need long-term residential care in a highdependency environment. How would you see the future of that kind of care? Where would you locate it? This kind of care is obviously going to be needed, and you have to find the money to provide the right type of not-too-large institution locally and to staff it. These are formidable problems, which I don't think we have yet really come to grips with. The difficulty in the long run is that the plan we've got is unsuitable for today's purpose, but when a government will find the money to develop what we do need, I don't know. I should be very worried about that kind of community care being provided in the private sector, because these people are very vulnerable and the nursing home scandals in the United States do warn one that things can go very wrong in private hands. I know they have gone wrong in the public sector also, but at least it's more possible then to do something about it, when a scandal blows up, and afterwards inspect it closely. I have an instinctive worry about vulnerable people being in private institutions, where you can't really expect them to know what's going on.

Would you see any future for a psychiatric hospital which is perhaps different from the kind that we've known in the past. Might there be a logic in having at least some such institutions in the future, though on $a$ smaller scale?

When you're thinking of the long-stay mentally ill, I never know the borderline between a hospital and a hostel, though perhaps that's a bit semantic. Some of the characteristics of each obviously need to be brought into whatever we call it. We choose to call it a hospital if it's funded by the NHS and a hostel if it's funded by social services, but to me it doesn't really matter what you call it. However, I'm quite convinced that there is a continuing need for some long-stay residential care, with of course psychiatric nursing and medical involvement. 